\title{
The Flow Change of Mixed and Hazardous Waste at Utena Regional Landfill
}

\author{
Ingrida Kepalaitè \\ Utena University of Applied Sciences, Faculty of business and technologies, Department of Environment \\ Protection, Address: Maironis Street 18, Utena
}

\begin{abstract}
While optimising the waste management, the Region waste management system - the system of regional waste management centres was created in Lithuania. Utena regional landfill is one of its elements. Since 2010 the waste flows were started to calculate by different fractions. Visually observing the waste disposal, it was noticed that the proportions of unsorted waste quantities flows were different in the districts, so it was decided that the custom random works of the mixed municipal waste content determination will be carried out in 2012 and 2013 four times a year, in different seasons. There is a possibility to dispose the sorted waste in Lithuania. Also, in all the municipalities there are Bulky and hazardous waste receiving and temporary storage sites, where the hazardous waste can be delivered. However, it was noticed that the sorting is insufficient - among the mixed municipal waste there are improper waste to be deposited, including the hazardous waste. The aim of the work is to analyze the change of the waste quantities at Utena regional landfill, distinguishing the quantities of the hazardous waste.
\end{abstract}

Keywords - mixed waste, hazardous waste, waste landfill, waste sorting.

\section{INTRODUCTION}

Since 2008, while optimising the waste management, the Region waste management system - the system of regional waste management centres was created in Lithuania, 11 regional non-hazardous waste landfills are open, waste sorting is installed. In the waste sites next to the blocks of flats, the sorted waste containers for paper and cardboard, plastic and metal, glass are full. In $2006-$ 2007, the condition of the waste deposition at that time was being analysed, the future situation was being forecasted, and the regional waste management plans were being created. The regional landfills started to operate in 2008 - 2009. Utena regional landfill started to operate in 2008.

It is important to analyze if the habits of the residents changed after the new opportunities arose, whether the waste quantities decrease as the population declines. Taking into account the fact that the hazardous waste must be collected and collected separately from other waste and must be not mixed with each others, except the cases if it is safer, it is important to determine the quantities of hazardous waste that are dropped off to the special sites and those that are dropped off with the mixed waste. In order to clarify these changes, one of the cleanest regions of Lithuania - Utena district - was chosen. Utena region waste management plan for 20082018 and Utena regional waste management centre reports of 2010 - 2012 were analyzed, and the flow change of the mixed and hazardous waste at Utena regional landfill was evaluated.

\section{UTENA REGIONAL WASTE MANAGEMENT CENTRE GENERAL REGION DESCRIPTION}

Utena region, which is situated in the north-east of Lithuania, covers the regions of Anyksciai, Ignalina, Moletai, Utena and Zarasai and the municipalities of
Visaginas, and its total area is $7201 \mathrm{~km}^{2}$. It's the fifth region in Lithuania according to the size of the area. It makes about $11 \%$ of the total country's territory. It's the land of the ravines, hills, lakes and forests. The district is rich with the underground water and sufficient quantities of explored underground drinking water. In the region of Utena there are existing sand, gravel and peat deposits. In the northern part there are wood resources. The forests cover $2228 \mathrm{~km}^{2}$ or $31 \%$ of the territory, and the waters cover $535 \mathrm{~km}^{2}$ (7,4\% of the total region territory). This region has the most of the lakes in Lithuania - 1002 lakes. Its landscapes are especially advantageous for the development of the recreation and tourism. The region of Utena has a relatively well-developed road network that connects the region with the other regions of the country and the neighboring countries. [7]

This information shows that the municipalities of Utena region should save its uniqueness and attractiveness to tourists and clean nature. One of the components of clean nature is a small quantity of waste that should be managed safely.

The biggest quantities of waste are formed in industry; domestic waste quantities are much smaller.

But in Lithuania the situation is opposite - here the quantity of the municipal waste is the biggest. The amount of waste depends on the industry development, the population change and the consumption growth. So, these major spheres, that form the biggest quantities of waste, are mostly represented by the industry branches which are particularly susceptible for materials and population. So, while calculating the outlook of the waste formation, three growth scenarios are used:

- slow growth scenario: the average annual consumption growth is $1 \%$;

- medium growth scenario: the average annual consumption growth is $3 \%$; 
- high growth scenario: the average annual consumption growth is $5 \%$.

The main areas of activity in the region are: machinebuilding and metal-working, textile and knitwear industry, construction and woodworking, trade, transport, food and beverage production, rural tourism. [7]

So, in the economic activity of the county there should not be a lot of waste, especially, the waste that are deposited.
In the Republic of Lithuania the population censuses were in 2001 and in 2011. In 2006, the Department of Statistics calculated the data that is why the figures do not match the data given by the local neighborhoods. The population figures in Utena region, according to the data of the Department of Statistics and the municipalities in the region, are given in the Table 1.

TABLE 1.

THE POPULATION FIGURES OF UTENA REGION IN 2006. [7]

\begin{tabular}{|l|l|l|l|l|l|l|}
\hline Municipality & $\begin{array}{l}\text { Population (the } \\
\text { data of the } \\
\end{array}$ & \multirow{2}{*}{$\begin{array}{l}\text { Pepartment of } \\
\text { Statistics) }\end{array}$} & $\begin{array}{l}\text { Population (the } \\
\text { neighborhoods) }\end{array}$ & & Population in cities & \multicolumn{2}{l|}{ Population in countries } \\
\cline { 5 - 7 } & 32.637 & 33.185 & 5.730 & 8.948 & 971 & $\begin{array}{l}\text { Individual } \\
\text { houses }\end{array}$ \\
\hline Anyksciai district & 20.625 & 22.501 & 4.345 & 2.755 & 3.656 & 17.536 \\
\hline Ignalina district & 23.540 & 23.540 & 4.884 & 2.337 & 3.500 & 11.745 \\
\hline Moletai district & 48.376 & 44.444 & 28.588 & 5.302 & 1.600 & 8.954 \\
\hline Utena district & 28.573 & 28.624 & 28.317 & - & 220 & 87 \\
\hline Visaginas city & 20.991 & 20.700 & 5.261 & 3.452 & 2.361 & 9.626 \\
\hline Zarasai district & 174.742 & 172.994 & 77.125 & 22.794 & 12.307 & 60.767 \\
\hline Total in region & & & & & Individual \\
\hline
\end{tabular}

Utena region is one of the least urbanized regions in Lithuania. 55\% of the district population lives in the cities. According to the data of the Department of Statistics of 2007, the biggest part of the population living in the rural areas is in the municipalities of Moletai and Ignalina. The majority of the population lives in the city only in Utena district $(68 \%)$ and in the municipality of Visaginas (99\%). The rural residential areas, having up to 10 residents, take the largest percentage in Utena district 39\%. [7]

TABLE 2.

THE POPULATION FIGURES OF UTENA REGION IN 2006 AND 2011. [1]

\begin{tabular}{|l|l|l|}
\hline Municipality & $\begin{array}{l}\text { Population in } \\
2006 .\end{array}$ & $\begin{array}{l}\text { Population in } \\
2011 .\end{array}$ \\
\hline $\begin{array}{l}\text { Anyksciai } \\
\text { district }\end{array}$ & 32637 & 28668 \\
\hline Ignalina district & 20625 & 18386 \\
\hline Moletai district & 23540 & 20700 \\
\hline Utena district & 48376 & 43275 \\
\hline Visaginas city & 28573 & 22585 \\
\hline Zarasai district & 20991 & 18390 \\
\hline Utena district & $\mathbf{1 7 4 7 4 2}$ & $\mathbf{1 5 2 0 0 4}$ \\
\hline
\end{tabular}

Table 2 and Figure 1 show the significant population decline in the district during the 5 year, especially in Visaginas city, Utena and Anyksciai districts. The population has decreased by nearly 23 thousand in Utena region.

Utena region is sparsely populated region in Lithuania, in 2006 the population density was $24,27 \mathrm{gyv} . / \mathrm{km}^{2}$. And in 2011 it was already decreased to $21,11 \mathrm{gyv} . / \mathrm{km}^{2}$.

The natural growth rate in Utena region is negative and is one of the lowest in all the region of the country. The population, comparing with the results of population census in 2011, has decreased in all the districts, mostly in Siauliai region - 18,5\% and Utena region - 18,3\%. [2]

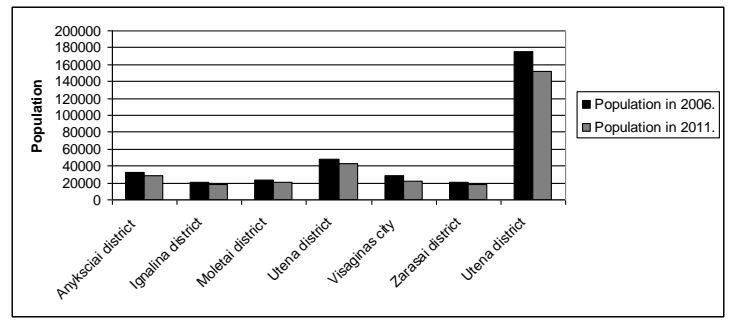

Fig. 1. The population figures of Utena region in 2006 and 2011. [1]

\section{WASTE MANAGEMENT SYSTEM IN UTENA DISTRICT}

In Lithuania about 1,3 million tons of municipal waste were formed or 392 kilograms for one resident in 2006; in 2007 - 1,35 million tons of municipal waste (401 kilogram for one resident); in 2008 - about 1,4 million tons of municipal waste (408 kilograms for one resident); in 2009 - about 1,2 million tons of municipal waste (361 kilogram for one resident). In $200686 \%$ of collected municipal waste were eliminated in the landfills, in 2007 $-91,8 \%$, in $2008-90,5 \%$, in $2009-90,6 \%$. It is obvious that the quantities of the collected waste slightly fluctuate every year, while the total amount of waste slightly increases. The same situation about the waste quantities is in Utena region. As the quantities of the waste were increasing, it was necessary to have the stricter waste management regulations; besides, it was demanded by EU law acts. In the Government of the Republic of Lithuania's resolution About The National Strategic Waste Management Plan Confirmation the shutdown of about 800 small landfills and the development of regional waste management system are foreseen. In Lithuania the 
waste are disposed in 11 regional non-hazardous waste landfills that meet the requirements of the environment protection and public health safety. The waste disposal in the landfills that do not meet the requirements of the environment protection and public health safety is stopped since 16 July, 2009. [5]

The waste landfill (storage) - is a waste disposal site where the waste are disposed of on ground or buried in the ground. The internal waste disposal sites are included here (i.e., the landfills where the formed waste are disposed by the waste producer in the place of its formation) but the sites, where the waste are stored in order to be prepared for the transportation to the other sites where they will be used and disposed, and the sites, where the waste are being stored temporally (up to one year) until they will be used or disposed, are not included. (Waste Management Act, article 2.15). [8]

So, the Region waste management systems were created in all the regions. While installing the waste management system in Utena district, the regional landfill was engineered by processing, extending and setting up Mockenai landfill (Utena district) according to all the environmental requirements. Mockenai landfill is being exploitable since 1986. The landfill area is 8,3 hectare, 7,6 hectare of that area is designated to dispose the waste, the rest of the area is used for the roads. At that moment, there were no surface water and filtrate collection systems, no treatment plants. While engineering the regional landfill, the accumulated waste, which in 2006 occupied 5,6 hectare area, were pushed together into the truncated pyramid-shaped mound, the old waste collection field was covered and re-cultivated. After joining the area of about 8 hectares to the existing territory, the regional landfill, meeting all the environmental requirements, was built in 2008. The landfill will be operated for about 20-25 years. The clamp of the regional landfill is planned to be set up in separate sections. The filtrate is collected by the drainage set up at the bottom of the clamp construction and led to the pumping station through which, together with the other contaminated wastewater of the landfill, will be passed to the treatment facilities of Utena city. It is planned to engineer the landfill gas collection system with the torch in the regional landfill. At the moment the torch is being used very rarely because methane, collected in the landfill, is sold to closed joint-stock company "Umaras". According to the fire norm requirements, fire tanks are engineered in the landfill. The special scales were installed to weigh the waste brought to the landfill. In the landfill territory, there is waste receiving site that is designated to collect the hazardous major, construction and household waste. There are also the temporary storage sites (one in each municipality), and two green waste composting sites: in the territory of Mockenai landfill, Utena district and in Karlai village (Visaginas municipality). [7]

There were only a few points in Lithuania where the waste was weighed until 2008. In the majority of the landfills the quantities of the waste were measured in cubic metres $\left(\mathrm{m}^{3}\right)$. In order to compare the amounts of waste from different regions, these quantities in cubic meters were converted to quantities in tons (according to the existing examples in the landfills, where the waste were weighed and measured in cubic metres), so they are not completely precise.

The recalculated statistical data on waste formation during 2005 and 2006 in Utena region were obtained from the regional municipalities. The provided data of $2010-$ 2012 are precise - the waste were weighed and registered at Utena regional landfill but relatively small quantities of waste that were brought by the residents themselves are not evaluated. The total amount of the waste formed in the municipalities of Utena district is given in Table 3 and in Figure 2

TABLE 3.

THE AMOUNT OF THE WASTE FORMED IN THE MUNICIPALITIES OF UTENA DISTRICT DURING 2005, 2006 AND 2010 - 2012, IN TONS. [7] [8]

\begin{tabular}{|l|l|l|l|l|l|l|}
\hline $\begin{array}{l}\text { Year/ Munici } \\
\text { pality }\end{array}$ & Anyksciai district & Ignalina district & Moletai district & Utena district & Visaginas city & Zarasai district \\
\hline 2005 & 9119,00 & 4300,00 & 5534,00 & 23007,20 & 6507,70 & 5000,00 \\
\hline 2006 & 9289,60 & 6297,60 & 5754,90 & 19989,90 & 6211,40 & 5500,00 \\
\hline 2010 & 5444,3 & 3677,88 & 5711,98 & 16127,2 & 5486,73 & 3941,04 \\
\hline 2011 & 5406,06 & 3247,18 & 5887,36 & 17115,7 & 5508,46 & 3685,5 \\
\hline 2012 & 4345,3 & 3087,48 & 5059,48 & 30772,71 & 4940,52 & 3328,36 \\
\hline
\end{tabular}


As it is obvious from the table and the picture, the total amount of the mixed waste has gradually decreased, except for Utena district. Besides, the tendencies in changes are different and uneven in different regions. Because the quantities of the waste are usually related to the population size and the industry development, so the provided data could partially correspond this tendency.

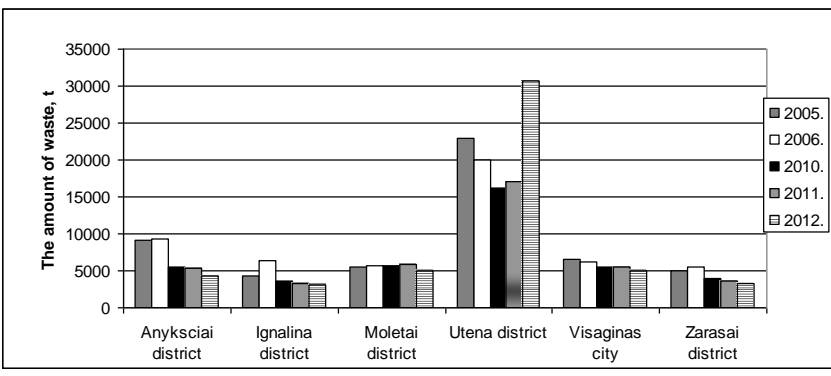

Figure 2. The amount of the waste formed in the municipalities of Utena district during 2005, 2006 and 2010 - 2012, in tons.

The growth of the waste quantity for one resident is obvious not only in the world but in Lithuania, too. After evaluating the growth of the sorted waste quantities, the opportunities to drop the waste off and be paid for it, Utena district is not regarded as exceptional.

42018 tons of municipal waste were formed in Utena region in 2006, it is 240 kilograms for one resident a year, which is significantly less than the average in Lithuania because the annual waste amount for one resident in Lithuania is 392 kilograms. The quantity of the mixed municipal waste, which is collected from the regional companies and organisations, is included in this amount. The industrial waste, separately collected recyclables, the bulky waste, the packaging waste, the construction and demolition waste and the sewage sludge from the water treatment plants are not included in this amount. [7]

\section{QUANTITIES OF HAZARDOUS WASTE}

In Lithuanian industry section about 4,3 million tons of waste were formed in 2006, 111 thousand tons of which were hazardous waste. In 2007 about 4,4 million tons of waste were formed in industry section and about 105 thousand tons of them were hazardous waste, in 2008 there were 4,4 million tons of waste, 109 thousand tons of which were hazardous waste, in 2009 - 3,8 million tons of waste were formed and about 103 thousand tons of them were hazardous waste. The hazardous waste in Lithuania are managed by the hazardous waste management companies. In 2006, 34 companies used the hazardous waste, in 2007 - 23 companies, in 2008 - 19 companies, in $2009-18$ companies. [5]

According to Waste Management Act, article 18, 1. the hazardous waste can not be diluted and mixed with other waste or materials during the processes of formation, sorting, storage, transportation, use, and disposal. 2. The hazardous waste can be mixed with other waste or materials only in the company of the hazardous waste use or disposal, if it is required by the hazardous wastes technical regulation. [8]

As the hazardous waste can not be disposed together with the mixed waste, the bulky and hazardous waste receiving and temporary storage sites were engineered in all the municipalities. Various waste are accumulated there: the bulky waste, waste containing asbestos, mixed construction and demolition waste, plastics, plastic packaging, textiles, paper and cardboard, glass packaging, glass, wood, metal, metal packaging, discarded electrical and electronic equipment, fluorescent lamps, oil filters, agrochemical waste, rubber waste, packages containing hazardous chemical substances, used oil, soil with hazardous chemicals, medicines, batteries and accumulators, discarded equipment containing chlorofluorocarbons, absorbents, cloths contaminated with chemicals and others. Figure 3 shows the total amounts of such waste that are accepted in the bulky and hazardous waste receiving and temporary storage sites in Utena region. [8]

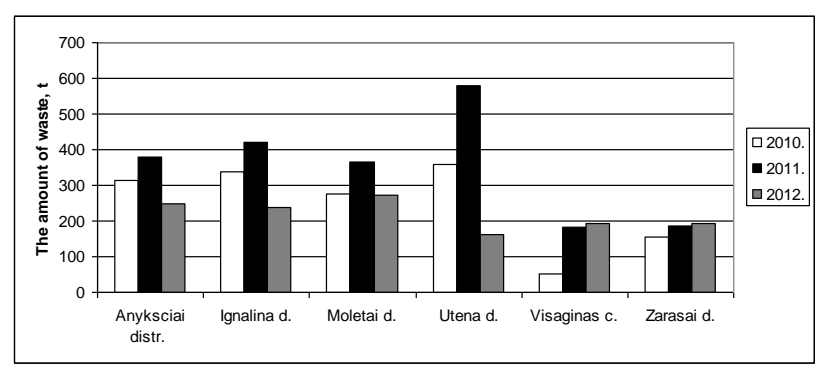

Fig. 3. Waste quantities in the bulky and hazardous waste receiving and temporary storage sites.

The picture shows, that the biggest quantities of the bulky, packaging and hazardous waste are in Utena city - the centre of industry and the district having the biggest population. There are visible signs of waste reduction in four sites in 2012, and there are two possible combined reasons for that - in these municipalities the information about the waste recycling importance was spread earlier and in a more intense way, and because the resident earlier did not know were to drop off the accumulated waste, they were dropped off in 2010 - 2011, while in 2012 only the newly formed waste were dropped off; as the society will become more conscious and the companies will install the new ISO systems, the quantities of such waste will gradually decrease in Lithuania, as well as in Visaginas city and the municipalities of Zarasai.

Because not all the waste accepted in the bulky and hazardous waste receiving and temporary storage sites are hazardous, it is important to identify the quantity of hazardous waste and to compare it with the total amount. Fig.4 shows the quantity of hazardous waste 


\section{Kepalaitè I. THE FLOW CHANGE OF MIXED AND HAZARDOUS WASTE AT UTENA REGIONAL LANDFILL}

(tons) in Utena comparing with the total amount of waste and the quantity of non-hazardous waste accumulated in the bulky and hazardous waste receiving and temporary storage site in Utena.

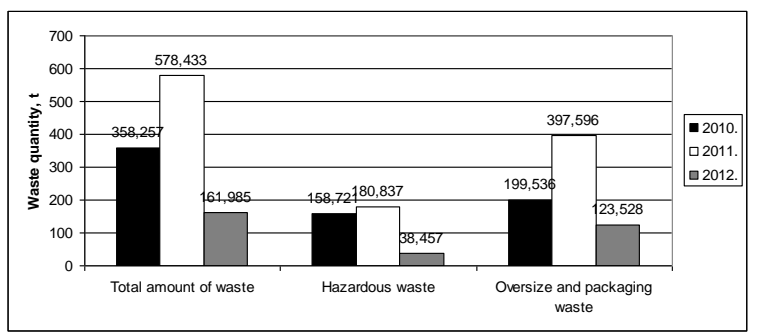

Fig. 4. Waste quantities in the bulky and hazardous waste receiving and temporary storage site in Utena.

It is visible that hazardous waste quantities are less comparing to the quantities of other waste accepted in the site and makes up significantly less than the half of the total amount of waste.
Table 4 shows the hazardous waste quantities, accepted in the bulky and hazardous waste receiving and temporary storage site in Utena regional waste management centre, which are grouped according to the waste lists approved in the replacement of the Environment Minister of the Republic of Lithuania December 30, 2003 No.722 decree About the Environment Minister of the Republic of Lithuania decree July 14, 1999 No.217 "about the approval of the waste management rules" [3] and in EU directive 2000/532/EC.[4].

As it is shown in the table, wide variety of hazardous waste are accepted and the quantities are very different - from very small to relatively big ones, and some kinds of the waste are dropped off not every year. Construction materials containing asbestos are distinctive in big quantities, the majority of these waste are made up by old asbestos slate.

TABLE 4.

THE HAZARDOUS WASTE QUANTITIES IN TONS IN THE BULKY AND HAZARDOUS WASTE RECEIVING AND TEMPORARY STORAGE SITE IN UTENA REGIONAL WASTE MANAGEMENT CENTRE [3] [4] [6]

\begin{tabular}{|c|c|c|c|c|}
\hline Waste code & Waste title & $2010 \mathrm{~m}$. & $2011 \mathrm{~m}$. & $2012 \mathrm{~m}$. \\
\hline $020108^{*}$ & agrochemical waste containing dangerous substances & 0,26 & 0 & 0 \\
\hline $060404 *$ & wastes containing mercury & 0 & 0,032 & 0 \\
\hline $130206^{*}$ & syntheticengine, gear and lubricating oils & 0,07 & 0 & 0 \\
\hline $130208^{*}$ & other engine, gear and lubricating oils & 0 & 0 & 0,08 \\
\hline $130507 *$ & oily water from oil/water separators & 6,174 & 5 & 0 \\
\hline $150202 *$ & $\begin{array}{l}\text { absorbents, filter materials (including oil filters not otherwise specified), } \\
\text { wiping cloths, protective clothing contaminated by dangerous substances }\end{array}$ & 0,04 & 0,03 & 0 \\
\hline $150110 *$ & packaging containing residues of or contaminated by dangerous substances & 0,006 & 0,01 & 0 \\
\hline $150111 *$ & metallic packaging & 0 & 0 & 0,017 \\
\hline $160107 *$ & oil filters & 0,018 & 0 & 0,017 \\
\hline $170503 *$ & soil and stones containing dangerous substances & 0,113 & 0 & 0 \\
\hline $170605 *$ & construction materials containing asbestos & 152,04 & 172,9 & 34,92 \\
\hline $200121 *$ & fluorescent tubes and other mercury-containing waste & 0 & 0,056 & 0,034 \\
\hline $200123 *$ & discarded equipment containing chlorofluorocarbons & 0 & 1,666 & 1,229 \\
\hline $200133 *$ & $\begin{array}{l}\text { batteries and accumulators, unsorted batteries and accumulator containing } \\
\text { these batteries }\end{array}$ & 0 & 0 & 0,023 \\
\hline $200135^{*}$ & discarded electrical and electronic equipment & 0 & 1,143 & 2,137 \\
\hline
\end{tabular}

A large part of the rural residents changes their roofing receiving the support from the Lithuanian Rural Development program for 2007 - 2013 and the rules of publicity of the provided support, approved by the decree of the Agriculture Minister of the Republic of Lithuania April 26, 2007, No. 3D-191.

So, using the partial funding, while improving their living conditions, the residents increased the amount of hazardous waste.

\section{HAZARDOUS WASTE ANALYSIS AMONG THE MIXED MUNICIPAL WASTE}

According to the decree of the Environment Minister of the Republic of Lithuania, No.D1-661 3108-2011 "About the content determination of the mixed municipal waste disposed at the regional landfills of non-hazardous waste and the approval of the assessment of procedure of the municipal biodegradable waste quantity in those landfills" at Utena regional non-hazardous waste landfill (address: Mockenai village, Utena parish, Utena district). The works of the determination of the mixed municipal waste content were carried out in spring, summer and autumn of 2012 and in winter of 2013, and they will be carried out in spring, summer and autumn (4 times a year), in order to find out the municipal waste content change, disposed in the landfill, during the different seasons. [6]

In order to determine the content of the mixed municipal waste in each municipality, random garbage trucks were chosen from Utena district, Anyksciai district, Ignalina district, Moletai district, Zarasai 
district and Visaginas municipalities. The carried out works were monitored by the representatives of Utena region environment protection department, Utena region municipalities and the administrators of the municipal waste management system established by the municipalities.

While carrying out January 2012 - 2013 analysis of the mixed waste, the waste amounts in tons were determined and calculated into per cents. It is surprising, that the conditions for waste sorting in Lithuania exist for several years now, but a large part of the mixed waste is made up of paper $(1-12,14 \%)$, if the paper quantity up to $2 \%$ is acceptable, so the bigger quantities show that the people are not interested in sorting the easily sorted waste. The plastic waste, including packages, in the total amount of the mixed waste make up $1,47-18,33 \%$. The metallic waste, including packages, in the total amount of the mixed waste make up $0,59-6,47 \%$. The glass waste, including packages, make up 1,18$12,06 \%$. A large quantity of these packages in the amount of the mixed waste can be justified because the packages have to be washed before sorting and that has some disadvantages, not all the packages can be thrown away to the containers but the existing amount of unsorted wastes is too big. A large amount, up to $15 \%$, of food waste is very surprising. There is no tendency that more waste of some particular kind is thrown away in some particular district. It is difficult to notice such tendencies during a year from four random garbage trucks from the district. The observed amount of particular waste (e.g. plastics) during one season is the smallest while during the other season it is the biggest, although the waste were taken from the same municipality. [6]

While preparing the regional waste management systems in 2007, it was also important to evaluate the content of the municipal waste. It was important to determine whether it would be useful to sort the waste. Table 5 shows the content of the municipal waste ( $\mathrm{kg} /$ resident/year) in 2007.

\section{TABLE 5.}

THE CONTENT OF THE MUNICIPAL WASTE (KG/RESIDENT/YEAR) 2007. [7]

\begin{tabular}{|l|l|}
\hline Fraction & Amount, \% \\
\hline Plastics & $9 \%$ \\
\hline Paper/cardboard & $14 \%$ \\
\hline Glass & $9 \%$ \\
\hline Metal & $3 \%$ \\
\hline Textile & $4 \%$ \\
\hline Biodegradable (kitchen and green) waste & $42 \%$ \\
\hline Combined packaging & $2 \%$ \\
\hline Construction and demolition waste & $4 \%$ \\
\hline Hazardous waste & $2 \%$ \\
\hline Other waste (leather, rubber, wood, and others) & $11 \%$ \\
\hline Total & $100 \%$ \\
\hline
\end{tabular}

After comparing the information of 2007 and 2012, it is noticeable that although the conditions for waste sorting exist, yet the proportions of the waste quantities remain similar.

For the analysis of the hazardous waste it is important to evaluate the quantity of the hazardous waste in the total amount of the mixed wastes at Utena regional landfill.

In Lithuania people are regularly informed about the importance of the waste sorting, about the danger that is caused by the hazardous waste being deposited in landfill. The batteries can be left in the majority of the shopping centres for a few years. It is financially worth to drop off old accumulators and electrical household appliances that are bought at the branches of the companies collecting recyclables which are located in all the municipalities since 2012. The contests of electronic waste and batteries collection are organised at schools. The residents can bring such waste to the temporary storage sites for free. Yet, some of such waste are still being brought to the landfills of non-hazardous waste.

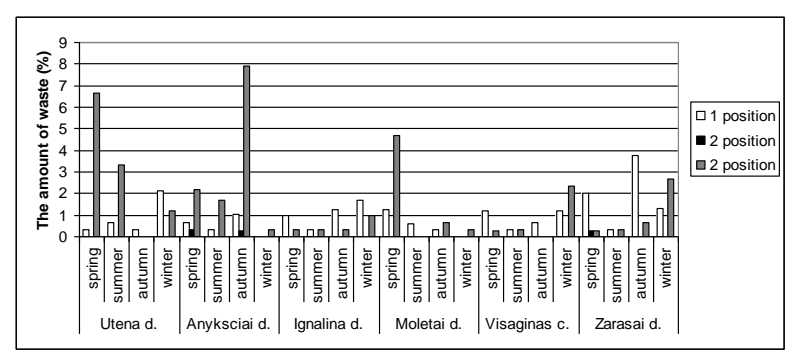

Fig. 5. The quantities of the hazardous waste among the mixed waste taken in at Utena Regional landfill.

For this analysis the most important thing is to evaluate the quantity of the hazardous waste among the mixed waste. During the analysis the hazardous waste were divided into 3 groups: 1) Electrical and electronic waste that were brought to the regional nonhazardous waste landfill at random, 2) Batteries and accumulators that were brought to the regional nonhazardous waste landfill at random, 3) Other hazardous waste that were brought to the regional non-hazardous waste landfill at random.

As it is shown in Picture 5, basically there are no batteries and accumulators or they make up less than $0,5 \%$. The larger amounts are only of that hazardous waste, which the residents can not throw away to the containers or to drop off close to home. But even these amounts are not regular in the same district in all four times. So, the increase of the hazardous waste up to 8 $\%$ in one garbage truck could be regarded as a coincidence, rather than the rule of the district. But the amounts of the hazardous waste up to $3 \%$ can already be regarded as a steady rate.

\section{CONCLUSIONS}

The municipalities of Utena region should save its uniqueness, attractiveness to tourists and clean nature. 
Kepalaitė I. THE FLOW CHANGE OF MIXED AND HAZARDOUS WASTE AT UTENA REGIONAL

\section{LANDFILL}

One of the components of clean nature (environment) is a small quantity of waste that should be managed safely. There should be not much waste formed because of the economic activities in the region. Especially those waste that are deposited.

The Region waste management systems were created in all the regions in Lithuania. The amount of waste depends on the industry development, the population change and the consumption growth. The total amount of the mixed waste has gradually decreased, except for Utena region. After comparing the information about the proportions of collected waste in 2007 and in 2012, it is noticeable that although the conditions for waste sorting exist, yet the proportions of the waste quantities remain similar.

The bulky and hazardous waste receiving and temporary storage sites are in all the municipalities. In Utena region, the biggest quantities of the bulky, packaging and hazardous waste are in Utena city - the centre of industry and the district having the biggest population. The quantities of the hazardous waste accepted in the region are much smaller than the quantities of other waste accepted in the site and make up significantly less than half of the total waste amount. A large variety of hazardous waste is accepted in the sites and their quantities are very different. The construction materials containing asbestos are distinctive in big quantities, the majority of these waste are made up by old asbestos slates.

Little quantities of the hazardous waste are still being brought to the mixed waste landfills. There are basically no batteries and accumulators or they make up less than $0,5 \%$. The larger amounts are only of that hazardous waste, which the residents can not throw away to the containers or to drop off close to home.

\section{REFERENCES}

[1] Department of Statistics of the Republic of Lithuania. [Online]. http://www.stat.gov.lt/lt/pages/view/?id=2630. [Accessed February 12, 2013].

[2] Department of Statistics of the Republic of Lithuania, 2011 Population and Housing Census. [Online].
[ http://www.stat.gov.lt/uploads/docs/Inform_gyv_sk_pasisk.pd f?PHPSESSID=a89d08a27449d72884e0179f9fac 1142 . [Accessed February 12, 2013].

[3] Environment Minister of the Republic of Lithuania December 30, 2003 No.722 decree About the Environment Minister of the Republic of Lithuania decree July 14, 1999 No.217 "about the approval of the waste management rules". [Online]. http://www3.lrs.lt/pls/inter2/dokpaieska.showdoc_1?p_id=232 336. [Accessed February 21, 2013].

[4] EU directive 2000/532/EC. [Online]. http://www.lewes.gov.uk/Files/EWC_31-03-09_CH.pdf. [Accessed February 21, 2013].

[5] Republic of Lithuania Government Resolution About the Approval of the National Strategic Waste Management Plan. [Online].

http://www3.lrs.1t/pls/inter3/dokpaieska.showdoc_1?p_id=388 766\&p_query $=\&$ p_tr2=2. [Accessed February 18, 2013].

[6] Utena regional waste management centre reports. [Online]. http://www.uratc.1t/index.php?option=com_content\&view=art icle\&id=53\&Itemid=33\&lang=lt. [Accessed February 11, 2013].

[7] Utena district waste management plan for 2008-2018. [Online].

http://www.uratc.lt/index.php?option=com_content\&view=art icle\&id=1\&Itemid=2\&lang=lt. [Accessed February 11, 2013].

[8] Waste Management Act of LR. [Online]. http://www3.lrs.lt/pls/inter3/dokpaieska.showdoc_1?p_id=440 990\&p_query $=\&$ p_tr2=2. [Accessed February 27, 2013]. 